\title{
KEDUDUKAN KETETAPAN MAJELIS PERMUSYAWARATAN RAKYAT (TAP. MPR) SEBELUM DAN SETELAH AMANDEMEN UUD 1945
}

\author{
AZWANI \\ Azwani86@yahoo.com \\ Fakultas Hukum \\ Universitas Mataram
}

\begin{abstract}
Abstrak
Penelitian bertujuan untuk menganalisis kedudukan Ketetapan MPR sebelum dan setelah perubahan UUD 1945. Penelitian ini menggunakan pendekatan mormatif yuridis. Dasar hukum Ketetapan MPR memang tidak diatur secara jelas dalam UUD 1945, walaupun demikian dasar hukum Ketetapan MPR dapat ditemukan melalui penafsiran sejumlah pasal yang ada dalam UUD 1945 seperti Pasal 3. Keberadaan dan penggunaan Ketetapan MPR selama ini telah diterima dan kenyataannya dapat bermanfaat dalam penyelenggaraan negara. Atas dasar kebiasaan tersebut maka keberadaan Ketetapan MPR diterima sebagai peraturan perundang-undangan dan dijadikan sebagai sumber hukum. Perubahan yang terjadi terhadap UUD 1945 selain merubah kedudukan MPR sebagai lembaga negara tertinggi, juga merubah tugas dan wewenang MPR. MPR tidak dibenarkan lagi mengeluarkan Ketetapan MPR yang bersipat mengatur keluar, seperti yang diatur pada Ketetapan MPRS No. XX/MPRS/1966 dan Ketetapan MPR No. III/MPR/2000 sebelumnya. Berdasarkan Undang-Undang Nomor 12 tahun 2011 yang di dalamnya menentukan jenis dan tata urutan peraturan perundang-undangan, yang menempatkan Ketetapan MPR/S dalam tata urutannya. Akan tetapi di sisi lain, kenyataannya masih terdapat sejumlah Ketetapan MPR/S yang dinyatakan masih berlaku dan dijadikan sebagai sumber hukum. Masih berlakunya sejumlah Ketetapan MPR/S tersebut didasari atas praktik ketatanegaraan atau kebiasaan ketatanegaraan Selain itu alasan Ketetapan MPR/S tetap diberlakuan untuk menghindari kekosongan hukum.
\end{abstract}

Kata kunci : Ketatapan MPR, Amandemen UUD

\section{A. Latar Belakang}

Pilihan bentuk putusan hukum Ketetapan MPR dapat didasarkan pada dua hal, yaitu : Pertama, Ketentuan-ketentuan yang tersirat dalam UUD 1945. Adanya ketentuan-ketentuan yang tersirat yang sekaligus mengandung kekuasaan tersirat (implied power) diakui oleh setiap sistem UUD. MPR menurut UUD 1945 mempunyai berbagai wewenang untuk melakukan tindakan atau membuat keputusan hukum seperti menetapkan Garis-garis Besar daripada Haluan Negara (GBHN), memilih dan mengangkat Presiden dan Wakil Presiden, serta mengubah UUD 1945. Keputusan-keputusan hukum ini harus diberi bentuk hukum tertentu. Keputusan hukum MPR antara lain diberi nama Ketetapan. Hal ini mungkin 
didasarkan pada bunyi Pasal 3 UUD 1945 (sebelum perubahan) yang menyebutkan : "Majelis Permusyawaratan Rakyat menetapkan Undang-Undang Dasar dan Garis-garis Besar daripada Haluan Negara”. Karena disebut "menetapkan" maka bentuknya diberi nama Ketetapan MPR. Kedua, Dasar bentuk hukum Ketetapan MPR adalah praktik ketatanegaraan atau kebiasaan ketatanegaraan. Praktik atau kebiasaan ketatanegaraan merupakan salah satu sumber hukum tata negara yang terdapat pada setiap negara.

Ketetapan MPR dapat dikatakan unik karena bentuk ini tidak ditemukan di negara lain. Oleh karena itu, mustahil menemukan materi muatan yang secara umum berlaku di setiap negara sehingga hanya mungkin dapat ditemukan di Negara Republik Indonesia. Bahkan UUD 1945 sebenarnaya tidak ditemukan kekuatan yang secara jelas mengatur tentang Ketetapan MPR. Bentuk Ketetapan MPR mulai dikenal sejak tahun 1960 yaitu sejak MPRS pertama kali bersidang dan membuat keputusan-keputusan. Praktik ini berjalan dan diteruskan oleh MPR. Karena telah berjalan cukup lama dan diterima sebagai praktik ketatanegaraan Indonesia, maka bentuk Ketetapan MPR dapat dipandang sebagai salah satu peraturan perundang-undangan Indonesia. Sistem Ketatanegaraan Indonesia mengakui kehadiran praktik atau kebiasaan ketatanegaraan seperti disebutkan dalam Penjelasan UUD 1945 :

"Undang-Undang Dasar suatu Negara ialah hanya sebagian dari hukumnya dasar negara itu, Undang-undang Dasar ialah hukum dasar yang tertulis, sedangkan di sampingnya Undang-Undang Dasar itu berlaku juga hukum dasar yang tidak tertulis, ialah aturan-aturan dasar yang timbul dan terpelihara dalam praktik penyelenggaraan Negara, meskipun tidak tertulis”. Perubahan Undang-Undang Dasar 1945 membawa akibat yang cukup mendasar terhadap lembaga-lembaga negara yang ada tidak terkecuali MPR. Setelah perubahan UUD 1945 MPR tidak lagi mempunyai wewenang untuk membentuk Ketetapan-ketetetapan MPR yang bersifat mengatur keluar, seperti membentuk Garis-garis Besar daripada Haluan Negara (GBHN). ${ }^{1}$ hal. 14.

${ }^{1}$ MPR, Materi Sosialisasi Putusan MPR RI, Sekjen MPR RI Jakarta, Cet. Kedua, Marat 2006, 
Perubahan kewenangan MPR dalam hal pembentukan Ketetapan MPR yang berlaku keluar membawa akibat pula pada kedudukan Ketetapan MPRS dan Ketetapan MPR dalam tata urutan (hierarki) peraturan perundang-undangan Republik Indonesia. Dimana di dalam tata urutan (hierarki) peraturan perundangundangan yang berlaku sekarang, yaitu berdasarkan Undang-Undang Nomor 12 Tahun 2011 Tentang Pembentukan Peraturan Perundang-Undangan menempatkan Ketetapan MPR dalam tata urutannya dan tidak lagi dijadikan sebagai salah satu sumber hukum. Namun, pada saat yang sama masih terdapat sejumlah Ketetapan MPRS dan Ketetapan MPR yang masih berlaku dan dijadikan sebagai sumber hukum.

\section{B. Perumusan Masalah}

Bertitik tolak dari apa yang telah diuraikan sebelumnaya maka, dapat dirumuskan permasalahan sebagai berikut : "Bagaimanakah kedudukan Ketetapan Majelis Permusyawaratan Rakayat (TAP. MPR) sebelum dan setelah Perubahan UUD 1945".

\section{C.Metode Penelitian}

Jenis penelitian yang digunakan dalam penelitian ini adalah jenis Penelitian Hukum Normatif. Penelitian hukum normatif adalah suatu proses untuk menemukan aturan hukum, prinsip-prinsip hukum maupun doktrin-doktrin hukum guna menjawab permasalahan hukum yang dihadapi. Dalam penulisan ini metode pendakatan yang dipakai adalah : Pendekatan Peraturan Perundangundangan (Statute Approach), Pendekatan Sejarah (Historical Approach) dan Pendekatan Konseptual (Conceptual Approach)

\section{Pembahasan}

Kedudukan Ketetapan MPR/S Sebelum Perubahan Undang-Undang Dasar 1945

\section{Dasar Hukum Ketetapan MPR/S}

Dasar hukum mengenai Ketetapan MPR/S dalam UUD 1945 memang tidak diatur secara jelas dan tegas seperti halnya undang-undang, peraturan pemerintah pengganti undang-undang, dan peraturan pemerintah. Walaupun 
demikian, dasar hukumnya dapat ditemukan melalui penafsiran sejumlah pasal yang ada dalam UUD 1945 (sebelum prubahan) antara lain :

Pasal 2 ayat (3) :

"Segala Putusan Majelis Permusyawaratan Rakyat ditetapkan dengan suara yang terbanyak".

Pasal 3 :

"Majelis Permusyawaratan Rakyat menetapkan Undang-Undang Dasar dan Garis-garis Besar daripada Haluan Negara”.

Pasal 6 ayat (2) :

"Presiden dan Wakil Presiden dipilih oleh Majelis Permusyawaratan Rakyat".

Dari ketentuan tersebut jelas, bahwa Negara Indonesia berdiri atas landasan kedaulatan rakyat. Kedaulatan rakyat itu dilaksanakan hanya oleh satu lembaga negara, yaitu MPR. Pelaksanaan kedaulatan rakyat diwujudkan melalui tugas dan wewenang yang diberikan kepada Majelis. Dari bunyi Pasal 2 ayat (3) yang menyatakan, "segala putusan Majelis Permusyawaratan Rakyat ditetapkan dengan suara terbanyak". Karena putusan MPR merupakan putusan sebuah lembaga negara yang berkedudukan di atas Presiden, DPR, BPK dan MA, maka bentuk peraturan yang dipilih harus di atas undangundang tetapi di bawah Undang-Undang Dasar.

Perlu diperhatikan bahwa, peraturan perundang-undangan hanya dapat dibentuk oleh lembaga-lembaga yang memperoleh kewenangan perundangundangan (wetgevingsbevoegdheid), yaitu kekuasaan untuk membentuk hukum (rechtsvorming). Mengenai hal itu tidak semua lembaga memperolehnya. Suatu lembaga akan memperoleh kewenangan baik secara atribusi maupun delegasi. Bagaimana dengan lembaga MPR. MPR tidak memperoleh kewenangan baik secara atribusi maupun delegasi untuk membentuk produk hukum yang bernama Ketetapan MPR. Tetapi, kewenangan membentuknya diperoleh berdasarkan kepada wewenang (tugas) yang di milikinya melalui UUD 1945 sebagaimana tersebut di atas. Sebenarnya wajar bahwa suatu lembaga negara membuat aturan, terutama 
yang menjadi kompetensinya dan terkait dengan masalah yang berada dalam yuridiksinya.

Selain berbentuk UUD 1945 dan Garis-garis Besar daripada Haluan Negara, UUD 1945 tidak memberi penjelasan lain tentang produk hukum MPR. Kendati demikian, seperti telah dikemukakan di atas bahwa, kehadiran Ketetapan MPR dapat didasarkan pada dua hal, yaitu : Pertama, Ketentuanketentuan yang tersirat dalam UUD 1945. Adanya ketentuan yang tersirat yang sekaligus mengandung kekuasaan tersirat (implied power) diakui oleh setiap sistem UUD. Kedua, Dasar bentuk hukum Ketetapan MPR adalah praktik ketatanegaraan atau kebiasaan ketatanegaraan. Praktik atau kebiasaan ketatanegaraan merupakan salah satu sumber hukum tata negara yang terdapat pada setiap negara.

Sistem Ketatanegaraan Indonesia mengakui kehadiran praktik atau kebiasaan ketatanegaraan seperti disebutkan dalam Penjelasan UUD 1945:

"Undang-Undang Dasar suatu Negara ialah hanya sebagian dari hukumnya dasar negara itu, Undang-undang Dasar ialah hukum dasar yang tertulis, sedangkan di sampingnya Undang-Undang Dasar itu berlaku juga hukum dasar yang tidak tertulis, ialah aturan-aturan dasar yang timbul dan terpelihara dalam praktik penyelenggaraan Negara, meskipun tidak tertulis".

Dalam kenyataannya terdapat Ketetapan MPR yang tidak dapat dikatagorikan sebagai peraturan perundang-perundangan. Ketetapan MPR tentang pengangkatan Presiden dan Wakil Presiden tidak mungkin digolongkan sebagai peraturan perundang-undangan karena bersifat kongkrit dan individual. Dalam Hukum Administrasi Negara, keputusan administrasi negara semacam Ketetapan MPR tentang Pengangkatan Presiden dan Wakil Presiden akan digolongkan sebagai beschikking bukan peraturan perundangundangan (wetgeving). Tetapi MPR tidak termasuk lembaga administrasi negara. Karena itu tidak mungkin menempatkan Ketetapan MPR tentang pengangkatan Presiden dan Wakil Presiden sebagai beschikking dalam arti salah satu bentuk keputusan administrasi negara. Dengan demikian, secara teoritis ilmiah ada dua jenis Ketetapan MPR yaitu yang berupa peraturan perundang-undangan dan keputusan MPR. 


\section{Kedudukan Ketetapan MPR/S Sebagai Sumber Hukum}

Sebenarnya masalah sumber hukum, khususnya tentang jenis-jenis peraturan perundang-undangan, tidak ditemukan secara sistematik dalam UUD 1945. Konstitusi ini hanya menyebut jenis-jenis peraturan perundangundangan secara terbatas dan tidak menegaskan herarkinya. Maka berkembanglah keanekaragaman legislasi dalam praktik ketatanegaraan Indonesia, seperti penggunaan Maklumat, Penetapan Presiden dan lain-lain. Tetapi, pada dasarnya UUD 1945 yang menjadi "sumber yang pertama dan tertib hukum yang pertama".

MPRS juga melakukan sistematisasi atas produk-produknya, yang terdiri atas : (1) Keputusan Musyawarah MPRS, yang menyangkut seluruh rakyat Indonesia serta mengandung arti dan maksud yang luas; (2) Keputusan Musyawarah Pimpinan MPRS, yaitu mengenai hal-hal tertentu dan terbatas. Tidak jelas seberapa terbatas jenis kedua produk MPRS ini, namun institusi Pimpinan MPRS mendapat pengukuhan selama Orde Baru karena berfungsi sebagai representasi dari lembaga, bahkan dirangkap dengan Pimpinan DPR. Fungsi Pimpinan MPR kemudian dipisahkan pasca Pemilu 1999, namun disatukan (dirangkap) dengan jabatan Badan Pekerja MPR.

Kemudian pada awal Orde Baru dilakukan sistematisasi sumber dan herarki peraturan perundang-undangan yang lebih komprehensif melalui Ketetapan No. XX / MPRS / 1966 Tentang Sumber Tertib Hukum dan Tata Urutan Peraturan Perundang-undangan. Dalam Ketetapan tersebut, ditentukan bentuk peraturan-peraturan dengan tata urutannya sebagai berikut :

1. Undang-Undang Dasar 1945;

2. Ketetapan MPR;

3. Undang-Undang/Perpu;

4. Peraturan Pemerintah;

5. Keputusan Presiden;

6. Peraturan-peraturan pelaksanaan lainnya seperti Peraturan Menteri, Instruksi Menteri, dan lain-lain. 
Sistematisasi tersebut yang diterapkan dalam kehidupan ketatanegaraan semasa Orde Baru, meskipun muncul praktik-prektik yang berlebihan dan menunjukkan dominisasi, bahkan otoritarianisme pihak eksekutif. Maka berkembanglah Keputusan Presiden (Kepres) yang bersipat "mengatur" (regulative), pada hal Ketetapan MPRS tersebut mendefinisikannya sebagai "keputusan yang bersifat khusus (einmahlig)".

Menurut Bagir Manan, ${ }^{2}$ jenis-jenis peraturan perundang-undangan yang diatur dalam Ketetapan MPR No. XX/MPR/1966 di atas ternyata lebih luas dari pada yang diatur dalam UUD 1945, tetapi lebih sempit dibandingkan dengan kenyataan yang ada. Dalam praktiknya terdapat peraturan-peraturan lain yang tidak disebutkan di atas, khususnya adalah Peraturan Tingkat Daerah.

Meskipun sistematisasi ini serupa dengan sistematisasi MPRS tahun 1966, tetapi antara keduanya tedapat sejumlah perbedaan mencolok yang bersipat problematik. Seperti keberadaan Peraturan Pemerintah Pengganti Undang-Undang (Perpu), dimana dalam sistematisisi sebelumnya keberadaan Perpu disetarakan dengan Undang-Undang yang berada pada urutan ketiga tetapi pada sistematisasi di atas ditempatkan pada urutan keempat, hal ini menimbulkan ketidak pastian status Perpu.

Menurut Jimly Asshiddqie ${ }^{3}$ penempatan Perpu pada urutan keempat di bawah undang-undang dapat menimbulkan penafsiaran seakan kedudukan Perpu itu berada di bawah undang-undang, padahal kedudukan hukum keduanya adalah sederajat. Oleh karena itu, seharusnya posisi Perpu ditempatkan seperti dalam Ketetapan No. XX/MPRS/1966, dimana keduanya ditempatkan pada urutan ketiga.

Penyusunan tata urutan peraturan perundang-undangan tersebut dimaksudkan untuk mengelompokkan norma-norma hukum perundangundangan sebagaimana dimaksudkan oleh teori yang dikemukakan oleh Hans Kelsen. Hans Kelsen mengemukakan bahwa suatu norma hukum dari negara

${ }^{2}$ Bagir Manan, Dasar-Dasar Perundang-Undangan Indonesia, Indo-Hill-Co, Jakarta, 1986, hal. 289-291.

3 Jimly Asshiddiqie, "Tata Urutan Perundang-Undangan dan Problem Peraturan Daerah" di sampaikan dalam rangka loka karya anggota DPRD se-Indonesia, di selenggarakan di Jakarta, Juam'at 22 Oktober 2000, hal. 17. 
manapun selalu berlapis-lapis dan berjenjang, dimana suatu norma hukum berlaku, berdasar dan bersumber pada norma hukum yang lebih tinggi, norma hukum yang lebih tinggi berlaku, berdasar dan bersumber pada norma hukum yang lebih tinggi lagi begitu seterusnya sampai pada suatu norma yang tidak dapat ditelusuri lebih lanjut. Atas dasar teori Hans Kelsen tersebut Hans Nawiasky, salah seorang murid dari Hans Kelsen mengelompokkan normanorma menjadi empat kelompok besar yaitu : ${ }^{4}$

Kelompok I : Staatfundamentalnorm (Norma Fundamental Negara)

Kelompok II : Staatgrundgesetz (Aturan Dasar/Pokok Negara)

Kelompok III : Formell Gesetz (Undang-Undang Formal)

Kelompok IV : Verordnung dan Autonome Satzung (Aturan Pelaksana dan Aturan Otonom)

Berdasarkan uraian tersebut terlihat adanya kesamaan pandangan antara Hans Kelsen dan dari Hans Nawiasky mengenai teori jenjang norma, bahwa norma itu berlapis-lapis dan berjenjang-jenjang. Tetapi Hans Kelsen lebih lanjut tidak mengelompokkan norma-norma itu sebagaimana yang dilakuakan oleh Hans Nawiasky. Selain perbedaan tersebut, Hans Nawiasky di dalam teorinya tidak menyebut Norma Dasar itu dengan sebutan Staatgrundnorm, melainkan dengan istilah Staatfundamentalnorm, pengertian Grundnorm menurutnya mempunyai kecenderungan untuk tidak berubah atau bersifat tetap, sedangkan di dalam suatu negara Norma Dasar itu dapat berubah sewaktu-waktu karena adanya pemberontakan, kudeta dan sebagainya. Mengenai perbedaan tersebut dapat digambarkan sebagai berikut.

Apabila melihat teori jenjang norma hukum dari Hans Nawiasky tersebut di Negara Republik Indonesia kelompok norma dari Staatgrundgesetz itu terdiri dari UUD 1945, Ketetapan MPR serta Hukum Dasar tidak tertulis. Ketentuan yang termuat dalam UUD 1945 dan Ketetapan MPR merupakan ketentuan yang masih bersifat umum dan garis besar dan masih merupakan norma tunggal karena masih belum ditentukan sanksi yang bersifat memaksa. Akan tetapi, ketika UUD 1945 dan Ketetapan MPR dimasukkan ke dalam tata urutan peraturan perundang-undangan (gesetz), hal

${ }^{4}$ Maria Farida Indarti Soeprapto, Op.Cit. 
itu mengundang kritik dari para teoritisi Hukum Tata Negara. Penggunaan istilah "peraturan perundang-undangan" dalam kedua sistematisasi yang sudah ada dalam hal ini dinilai tidak tepat karena dengan istilah peraturan perundang-undangan, dimana dalam teori di atas berarti menyangkut pengelompokkan norma. Jika hal ini yang dimaksudkan, maka pencantuman Ketetapan MPR dan UUD 1945 dalam tata urutan itu menjadi tidak tepat karena berdasarkan pengelompokan norma, Ketetapan MPR dan UUD 1945 bukan termasuk peraturan perundang-undangan (gesetz), tetapi dimasukkan dalam kelompok staatsgrundgesetz.

\section{Kedudukan Ketetapan MPR/S Setelah Perubahan UUD 1945}

\section{Peninjauan Materi dan Status Hukum Ketetapan MPR/S}

Perubahan keempat Undang-Undang Dasar Negara Republik Indonesia Tahun 1945 telah menegaskan bahwa perubahan Undang-Undang Dasar Negara Republik Indonesia Tahun 1945 mulai berlaku pada tanggal ditetapkan, yaitu tanggal 10 Agustus 2002. Namun, pada saat itu masih terdapat sejumlah Ketetapan MPRS dan Ketetapan MPR yang masih berlaku. Sejak tahun 1960 sampai tahun 2002 ada 139 Ketetapan MPRS dan Ketetapan MPR yang secara hukum masih berlaku. Oleh karena itu UUD 1945 melalui Majelis Permusyawaratan Rakyat ditugasi untuk melakukan peninjauan terhadap materi dan status hukum Ketetapan MPRS dan Ketetapan MPR tersebut.

Tugas seperti ini bukanlah hal yang baru dalam sejarah MPR. Pada masa Orde Baru MPRS dan MPR pernah meninjau beragam produk-produk hukum, dengan melakukan hal-hal sebagai berikut $:^{5}$

1. Melihat kesesuaian antara isi dan tujuan dengan kehendak rakyat. Apabila materinya sudah atau masih sesuai maka dituangkan dalam undang-undang, jika tidak sesuai maka dinyatakan tidak berklaku.

2. Melihat kesesuaian materi yang diatur dengan konstitusi, apabila bertentangan dengan konstitusi maka dicabut atau dihapus.

3. Melihat kesesuaian dengan kondisi dan situasi sekarang yang dilakukan dengan cara meneliti perubahan yang terajadi dibidang

\footnotetext{
${ }^{5}$ Riri Nazriyah, Op.Cit., hal. 186.
} 
politik ketatanegaraan, ekonomi, sosial dan budaya untuk dirumuskan kebijakan baru.

4. Mengelompokkan sejumlah ketetapan dalam katagori einmahlig.

Sebagai konsekkuensi dari langkah-langkah tersebut, MPRS dan MPR telah melakukan beberapa hal. Pertama, mencabut sejumlah produk hukum karena dinilai bertentangan dengan Pancasila, contoh : Ketetapan No. IV/MPRS/1963 tentang Pedoman-pedoman Pelaksanaan Garis-garis Besar Haluan Negara dan Haluan Pembangunan, Ketetapan No. VIII/MPRS/1965 tetang Prinsip-prinsip Musyawarah/Perwakilan. Kedua, mencabut sejumlah produk hukum karena dinilai bertentangan dengan UUD 1945 Contoh : Ketetapan No. XXXVII/MPRS/1968. Ketiga, merevisi, seperti atas Ketetapan No. XII/MPRS/1966 tentang Penegasan Kembali Landasan Kebijaksanaan Politik Luar Negeri RI. Keempat, menuangkan materinya ke dalam peraturan perundang-undangan. Kelima, menyatakan sebagai ketetapan yang einmahlig, contohnya Ketetapan No. IX/MPR/1973 tentang Pengangkatan Presiden RI.

Selain itu, suatu model peninjauan terhadap Ketetapan MPR/S juga dapat dilihat dalam Ketetapan No.V/MPR/1973 sebagai berikut : a). menyatakan tidak berlaku dan mencabut ketetapan ; b). menyatakan ketetapan tidak berlaku karena materinya sudah tertampung dalam GBHN ; c). menyatakan tetap berlaku dan disempurnakan ; d). materi ketetapan belum tertampung dan tidak bertentangan dengan GBHN 1973 akan diatur dalam peraturan perundang-undangan.

Mengenai peninjauan materi dan status hukum Ketetapan MPR/S dari tahun 1960 sampai dengan 2002 tersebut, muncul berbagai pendapat yang berkembang dalam panitia Ad Hoc II Badan Pekerja MPR. Berikut ini pokokpokok dari berbagai pendapat tersebut :

1. Salah satu kelompok pendapat menyatakan :

a. Bahwa Ketetapan MPRS dan MPR setelah Amandemen UUD 1945 sudah tidak ada lagi dalam Tata Urutan Perundangundangan, sedangkan terhadap materi Ketetapan MPR yang masih berlaku dituangkan dalam bentuk undang-undang. 
b. Bahwa sepanjang materi Ketetapan MPRS dan MPR dianggap masih diperlukan, maka ketetapan tersebut tetap berlaku walaupun ke depan MPR tidak lagi membuat ketetapan MPR.

2. Kelompok pendapat lain menyatakan bahwa mengingat ke depan MPR tidak lagi membuat putusan-putusan, maka terhadap Ketetapan MPRS dan Ketetapan MPR yang ada masih perlu ada putuan dalam Sidang MPR tahun 2003 yang bersifat menyeluruh atau "SAPU JAGAD” yang pada intinya :

a. Semua putusan yang bertentangan dengan undang-undang dasar tidak berlaku lagi sehingga Ketetapan MPR/S tertentu perlu ditinjau kembali.

b. Substansi penting yang ada / termuat dalam Ketetapan MPR/S dituangkan pada undang-undang untuk mengaturnya.

3. Sedangkan mengenai kemungkinan substansi putusan tersebut dapat mengandung hal-hal sebagai berikut :

a. Ketetapan MPR/S yang bersifat einmahlig berlaku sekali (beberapa banyak ketetapan yang besifat einmahlig perlu diberi catatan).

b. Ketetapan MPR/S yang berlaku insedentil / kebijakan sementara (perlu diberi catatan).

c. Ketetapan MPR/S yang berlaku jangka panjang :

1) Dicabut dan substansinya diserahkan kepada undang-undang.

2) Dicabut dan substansinya dihapus / dinyatakan tidak berlaku lagi.

3) Dicabut :

a) Materinya sudah masuk undang-undang dasar;

b) Materinya sudah masuk undang-undang;

c) Mengenai putusan tentang undang-undang dasar akan tetap berlaku sampai dengan diadakan perubahan berikut.

Keragaman pendapat yang muncul dalam panitia Ad Hoc II Badan Pekerja MPR menunjukkan ketidakjelasan makna terkait mengenai meninjau materi Ketetapan MPR dan status Ketetapan MPR. Apakah makna meninjau 
berarti mempelajari kembali Ketetapan MPR/S yang diterbitkan antara tahun 1960-2002. Badan Pekerja MPR sendiri menggunakan UUD 1945 hasil perubahan sebagai acuan dalam melakukan peninjauan.

Dari pendapat yang berkembang dapat dijelaskan sebagai berikut : Pertama, berdasarkan pengalaman historis, peninjauan materi dan status hukum Ketetapan MPR dapat berarti mencabut atau tetap memberlakukan seluruh ketetapan dari tahun 1960-2002, atau sekedar merivisi ketetapanketetapan tesebut. Kedua, UUD sendiri tidak menentukan herarki perundangundangan. Dalam kenyataan secara normaif antara satu peraturan dengan peraturan perundang-undangan yang lain bisa saling terkait, sehingga apabila peraturan tersebut dicabut dapat mempengaruhi eksistensi peraturan perundang-undangan yang terkait. Ketiga, sebagai konsekkuensi dari pencabutan atau penghapusan dari peraturan perundang-undangan tertentu (dalam hal ini Ketetapan MPR/S) dapat menimbulkan kekosongan hukum, dan pada gilirannya dapat menimbulkan ketidak pastian dan / atau ketidakadilan.

Berdasarkan pengkajian Panitia Ad Hoc II Badan Pekerja MPR, dari beberapa pengkategorian yang ada bahwa beberapa Ketetapan MPR/S yang masih pasti keberadaannya karena masih perlu dilakukan tindakan hukum lebih lanjut dan masih perlu dilakukan pengkajian yaitu ketetapan yang masuk ke dalam Katagori II dan Katagori IV. Sedangkan Kategori I, III,V dan VI sudah terpenuhi ketentuannya atau sudah selesai dilaksanakan dan tidak memerlukan tindakan hukum lebih lanjut.

Kategori Pertama, berdasarkan ketetapan tersebut sudah dinyatakan tidak berlaku lagi atau sudah dinyatakan dicabut. Kategori Ketiga, sudah dinyatakan tidak berlaku lagi karena pemerintahan hasil Pemilu 2004 sudah terbentuk. Kategori Kelima, Karena keempat ketetapan yang ada dalam kategori kelima dan ditambah satu ketetapan (Ketetapan MPR RI Nomor II/MPR/2003) yang merupakan Peraturan Tata Tertib MPR yang mengatur tata cara Majelis dalam rangka melaksanakan tugas sesuai kedudukan, tugas dan wewenangnya, sudah tidak berlaku lagi karena telah terbentuknya 
Peraturan Tata Tertib MPR hasil Pemilu 2004. Sedangkan Katagori Keenam dinyatakan sebagai ketetapan yang bersipat final (einmahlig), sudah dicabut maupun sudah selesai dilaksanakan sehingga tidak perlu dilakukan tindakan hukum lebih lanjut.

\section{Kedudukan Ketetapan MPR/S Sebagai Sumber Hukum}

Sebagaimana telah dikemukakan bahwa masalah sumber hukum, khususnya tentang jenis-jenis peraturan perundang-undangan, tidak ditemukan secara sistematik dalam UUD 1945. Konstitusi ini hanya menyebut jenis-jenis peraturan perundang-undangan secara terbatas dan tidak menegaskan hierarkinya. Karena tidak diatur secara jelas hierarki peraturan perundang-undangan dalam UUD 1945, maka MPR Melalui Ketetapan MPRS No. XX/MPRS/1966 dan Ketetapan MPR No. III/MPR/2000 menentukan sistematisasi peraturan perundang-undangan dengan tata urutannya dan dalam kehidupan ketatanegaraan dijadikan sebagai sumber hukum.

Selama ini, Ketetapan MPR/S berada dalam urutan kedua setelah UUD 1945 dalam tata urutan peraturan perundang-undangan dan menjadi sumber hukum bagi peraturan perundang-undangan yang berada di bawah nya. Kemudian muncul pertanyaan, bagaimanakah kedudukan Ketetapan MPR dalam tata urutan peraturan perundang-undangan setelah adanya perubahan UUD 1945, apakah statusnya masih diakui dan bagaimana statusnya sebagai sumber hukum apakah masih diakui. Berkaitan dengan hal tersebut Bagir Manan ${ }^{6}$ mengemukakan bahwa, kehadiran lebih lanjut Ketetapan MPR sebagai peraturan perundang-undangan tergantung pada keberadaan MPR. Kalau terjadi perubahan terhadap lembaga ini menjadi sistem dua kamar, Ketetapan MPR dengan sendirinya terhapus. Keberadaan Ketetapan MPR hanya terbatas pada wewenang MPR yang secara tegas disebutkan dalam UUD. Kalau dari wewenang ini tidak ada yang dapat diatur sebagai peraturan perundang-undangan, maka Ketetapan MPR tidak akan ada dalam sistem peraturan perundang-undangan.

\footnotetext{
${ }^{6}$ Riri Nazriyah, Ibid., hal. 293.
} 
Dengan demikian, MPR di masa yang akan datang tidak dapat lagi menerbitkan Ketetapan MPR yang bersifat mengatur keluar, maka Ketetapan MPR yang selama ini berada dalam tata urutan peraturan perundangundangan harus dikeluarkan. Kendati demikian, mengacu kepada teori kedaulatan rakyat yang diatur oleh UUD 1945, MPR masih mempunyai wewenang untuk mengatur sistem ketatanegaraan Indonesia yaitu melalui wewenang yang dimilikinya untuk menetapkan UUD 1945.

Masalah konstitusionalitas Ketetapan MPR di antara ahli hukum tata negara menimbulkan perbedaan pendapat. Pendapat yang mengatakan bahwa Ketetapan MPR adalah inkonstitusional beralasan bahwa Ketetapan MPR tidak diatur dalam UUD 1945, sehingga Harun Al-Rasyid ${ }^{7}$ menyebut Ketetapan MPR sebagai barang haram. Pendapat yang mengatakan bahwa Ketetapan MPR adalah konstitusional beralasan bahwa kehadiran bentuk Ketetapan MPR berdasarkan kepada ketentuan-ketentuan yang tersirat dalam UUD 1945.

Adanya pernyataan bahwa Ketetapan MPR itu bukan merupakan peraturan perundang-undangan dapat dengan mudah digali dan dipahami dari dua pasal di dalam UUD yakni Pasal 24 C ayat (1), Aturan Tambahan Pasal I serta Tap. MPR Nomor I/MPR/2003 dan Undang-Undang Nomor 10 Tahun $2004:^{8}$

a. Pasal $24 \mathrm{C}$ ayat (1) menggariskan bahwa "Mahkamah Konstitusi berwenang mengadili pada tingkat pertama dan terakhir yang putusannya bersifat final untuk menguji undang-undang terhadap Undang-Undang Dasar...,"dan seterusnya. Ini berarti bahwa peraturan perundang-undangan yang langsung berada di bawah UUD adalah UU. Kalau seandainya ada Tap MPR di bawah UUD maka ketentuan pengujiannya tentu akan menentukan bahwa MK menguji Tap MPR terhadap UUD dan/atau menguji UU terhadap Tap MPR. Dengan demikian jelas bahwa Tap MPR bukanlah peraturan perundangundangan.

b. Aturan tambahan Pasal I UUD hasil amandemen menentukan bahwa "Majelis Permusyawaratan Rakyat ditugasi untuk melakukan peninjauan terhadap materi dan status hukum Ketetapan Majelis Permusyawaratan Rakyat Sementara dan Ketetapan Majelis

\footnotetext{
${ }^{7}$ Riri Nazriah, Ibid., hal. 294.

${ }^{8}$ Mahfud MD, Perdebatan Hukum Tata Negara pasca Amandemen Konstitusi, Pustaka LP3ES Indonesia, Jakarta, 2007, hal. 32-33.
} 
Permusyawaratan Rakyat untuk diambil putusan pada Sidang MPR tahun 2003." Ketentuan ini jelas memerintahkan kepada MPR untuk meninjau dan menentukan status baru bagi semua Tap MPR/MPRS yang sudah ditetapkan bukan sebagai peraturan perundang-undngan lagi. Jadi ketentuan Aturan Tambahan ini dibuat karena Tap MPR bukan lagi sebagai peraturan perundang-undangan sehingga harus dibuat status baru untuk yang sudah ada dan terlanjur menjadi peraturan perundang-undangan.

c. Berdasarkan ketentuan UUD hasil amandemen atas status Tap MPR dan Tap MPRS itu maka Sidang Tahunan MPR tahun 2003 mengeluarkan Tap MPR yang (secara populer) dikenal sebagai "Tap Sapujagat" yakni Tap Nomor I/MPR/2003 tentang Peninjauan Terhadap Materi dan Status Hukum Ketetapan MPRS dan Ketetapan MPR RI Tahun 1960 Sampai Dengan Tahun 2002. Tap ini mengelompokkan 139 Tap MPRS dan Tap MPR yang sudah ada ke dalam enam kelompok status baru, yaitu : (1) yang dicabut dan dinyatakan tidak berlaku sebanyak 8 Tap, (2) yang dinyatakan tetap berlaku dengan ketentuan tertentu sebanyak 3 Tap, (3) yang dinyatakan tetap berlaku sampai dengan terbentuknya pemerintahan hasil pemilu sebanyak 8 Tap, (4) yang dinyatakan tetap berlaku sampai dengan terbentuknya UU sebanyak 11 Tap, (5) yang dinyatakan masih berlaku sampai dengan ditetapkannya Peraturan Tata Tertib baru oleh MPR hasil Pemilu 2004 sebanyak 5 Tap, (6) yang dinyatakan tidak perlu dilakukan tindakan hukum lebih lanjut, baik karena bersifat final (einmahlig), telah dicabut, maupun telah selesai dilaksanakan sebanyak 104 Tap.

d. Undang Undang (UU) Nomor 10 Tahun 2004 tentang Pembentukan Peraturan Perundang-undangan yang dibuat, antara lain, untuk menyesuaikan dengan tuntutan UUD 1945 hasil amandemen itu menetapkan jenis-jenis dan hierarki peraturan perundang-undangan dengan tidak lagi memasukkan Tap MPR sebagai peraturan perundang-undangan.

Semenjak tahun 1960 sampai dengan Sidang Umum Tahunan 2002, MPR telah mengeluarkan Ketetapan MPR/S sebanyak 139 Ketetapan MPR/S. Banyaknya Ketetapan MPR/S tersebut tidak terlepas dari luasnya wewenang yang dimiliki oleh MPR sebelum perubahan UUD 1945. Namun, Ketetapanketetapan MPR tersebut menunjukkan tidak semua Ketetapan MPR/S yang selama ini ada dapat dikatakan sepenuhnya mengacu pada tiga tugas dan wewenang MPR menurut UUD 1945, melainkan lebih banyak mendasarkan diri pada kedudukannya, dengan segala interpretasinya.

Berdasasarkan hasil peninjauan terhadap Ketetapan MPR/S sebagaimana dikemukakan sebelumnya bahwa wewenang yang dimiliki oleh 
MPR setelah perubahan UUD 1945. MPR tidak lagi berwenang untuk menerbitkan Ketetapan MPR yang bersifat mengatur keluar (regeling) sehingga Ketetapan MPR harus dikeluarkan dari tata urutan (hierarki) peraturan perundang-undangan.

Dalam rangka penataan kembali sumber tertib hukum dan tata urutan peraturan perundang-undangan RI telah dikeluarkan Undang-Undang Nomor 12 tahun 2011 tentang Pembentukan Peraturan Perundang-undangan. Di dalam salah satu pasalnya mengatur tata urutan perundang-undangan dengan tmenempatkan Ketetapan MPR/S dalam tata urutannya. Ketentuan mengenai jenis dan tata urutan peraturan perundang-undangan dapat dilihat dalam Pasal 7 ayat (1) yang terdiri dari :

1. Undang-Undang Dasar Negara Republik Indonesia Tahun 1945;

2. Ketetapan MPR

3. Undang-Undang/Peraturan Pemerintah Pengganti Undang-Undang;

4. Peraturan Pemerintah;

5. Peraturan Presiden;

6. Peraturan. Daerah Provinsi

7. Peraturan Daerah Kabupaten/kota

Seperti telah dikemukakan di atas bahwa, kehadiran Ketetapan MPR sebagai sumber hukum dapat didasarkan pada dua hal, yaitu : Pertama, Ketentuan-ketentuan yang tersirat dalam UUD 1945. Adanya ketentuan yang tersirat yang sekaligus mengandung kekuasaan tersirat (implied power) sebagaimana yang dimiliki MPR, diakui oleh setiap sistem UUD. Kedua, Dasar bentuk hukum Ketetapan MPR adalah praktik ketatanegaraan atau kebiasaan ketatanegaraan. Selain itu keberadaan Ketetapan MPR tetap dipertahankan untuk menghindari timbulnya kekosongan hukum yang akibatnya dapat menimbulkan ketidakpastian atas status peraturan-peraturan yang berkaitan dengan ketetapan-ketetapan itu sendiri. Di dalam UUD 1945 setelah perubahan Pasal I Aturan Peralihan dijelaskan bahwa "Segala peraturan perundang-undangan yang ada masih tetap berlaku selma belum diadakan yang baru menunrut UUD ini”. 


\section{E.Kesimpulan}

Berdasarkan hasil pembahasan pada bab sebelumya maka dapat ditarik beberapa kesimpulan sebagai berikut :

1. Dasar hukum Ketetapan MPR memang tidak diatur secara jelas dalam UUD 1945, walaupun demikian dasar hukum Ketetapan MPR dapat ditemukan melalui penafsiran sejumlah pasal yang ada dalam UUD 1945 seperti Pasal 3. Keberadaan dan penggunaan Ketetapan MPR selama ini telah diterima dan kenyataannya dapat bermanfaat dalam penyelenggaraan negara. Atas dasar kebiasaan tersebut maka keberadaan Ketetapan MPR diterima sebagai peraturan perundang-undangan dan dijadikan sebagai sumber hukum. Kejelasan pengaturan mengenai Sumber Hukum dan Tata Urutan Peraturan Perundang-undangan dalam UUD 1945 memang tidak ditemukan. Sejarah ketatanegaraan menunjukkan bahwa mengenai sumber hukum dan tata urutan peraturan perundang-undangan telah mengalami beberapa kali pergantian. Keberadaan Ketetapan MPR sebagai sumber hukum dapat ditemukan dalam beberapa sistematisasi peraturan perundang-undangan. Pada awal Orde Baru ditentukan melalui Ketetapan MPRS No. XX/MPRS/1966 tentang Sumber Hukum dan Tata Urutan Peraturan Perundang-undangan. Pada masa reformasi ditentukan melalui Ketetapan MPR No. III/MPR/2000 tentang Sumber dan Tata Urutan Peraturan Perundang-undangan. Dalam kedua ketetapan tersebut Ketetapan MPR/S diletakkan pada urutan kedua.

2. Perubahan yang terjadi terhadap UUD 1945 selain merubah kedudukan MPR sebagai lembaga negara tertinggi, juga merubah tugas dan wewenang MPR. MPR tidak dibenarkan lagi mengeluarkan Ketetapan MPR yang bersipat mengatur keluar, seperti yang diatur pada Ketetapan MPRS No. XX/MPRS/1966 dan Ketetapan MPR No. III/MPR/2000 sebelumnya. Berdasarkan UndangUndang Nomor 12 tahun 2011 yang di dalamnya menentukan jenis dan tata urutan peraturan perundang-undangan, yang menempatkan Ketetapan MPR/S dalam tata urutannya. Akan tetapi di sisi lain, kenyataannya masih terdapat sejumlah Ketetapan MPR/S yang dinyatakan masih berlaku dan dijadikan sebagai sumber hukum. Masih berlakunya sejumlah Ketetapan MPR/S tersebut didasari atas praktik ketatanegaraan atau kebiasaan ketatanegaraan yang diakui 
oleh Indonesia dan Pasal I Aturan Peralihan yang mengakui keberlakuan peraturan perundang-undangan yang sudah ada sebelum ada yang baru menurut UUD. Selain itu alasan Ketetapan MPR/S tetap diberlakuan untuk menghindari kekosongan hukum.

\section{Daftar Pustaka}

Bagir Manan, Dasar-Dasar Perundang-Undangan Indonesia, Indo-Hill-Co, Jakarta, 1986, hal. 289-291

MPR, Materi Sosialisasi Putusan MPR RI, Sekjen MPR RI Jakarta, Cet. Kedua, Marat 2006,

Jimly Asshiddiqie, "Tata Urutan Perundang-Undangan dan Problem Peraturan Daerah" di sampaikan dalam rangka loka karya anggota DPRD seIndonesia, di selenggarakan di Jakarta, Juam'at 22 Oktober 2000

Mahfud MD, Perdebatan Hukum Tata Negara pasca Amandemen Konstitusi, Pustaka LP3ES Indonesia, Jakarta, 2007,

Riri Nazriah, MPR RI Kajian Terhadap Produk Hukum dan Prospek di Masa Depan, FH UII PRESS, Yogyakarta, Oktober 2007

Maria Farida Indarti Soeprapto, Ilmu Perundang-Undangan, Kansius, Yogyakarta, Cet. Ketujuh, 2002,

Indonesia UUD Negara RI Tahun 1945 